脊椎椎間板ヘルニアに抢ける尿流動態検査成績

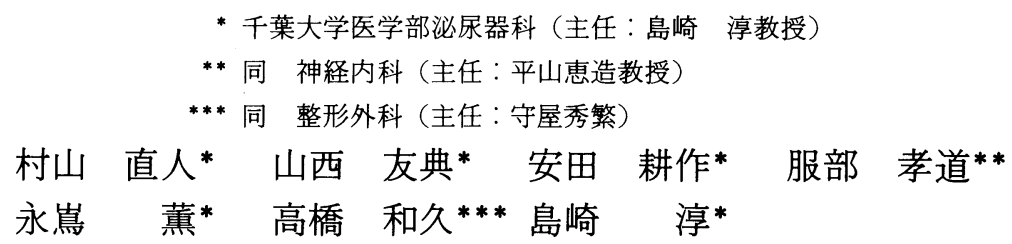

\title{
URODYNAMIC STUDIES IN PATIENTS WITH INTERVERTEBRAL PROLAPSE
}

\author{
Naoto Murayama*, Tomonori Yamanishi*, Kosaku Yasuda*, Takamichi Hattori**, \\ Kaoru Nagashima*, Kazuhisa Takahashi*** and Jun Shimazaki* \\ *Department of Urology, School of Medicine, Chiba University \\ **Department of Neurology, School of Medicine, Chiba University \\ ***Department of Orthopaedic Surgery, School of Medicine, Chiba University
}

Thirty-one patients with intervertebral disc prolapse (IDP) underwent urodynamic study before surgical operation. The lesion was located between C4 and T10 in 14, T11 and L2 in 2 and L2 and S1 in 15 patients. Preoperative urinary symptoms were obstructive in $11(36 \%)$, irritative in $5(16 \%)$ and both obstructive and irritative in $5(16 \%)$ patients, and the remaining 19 patients $(32 \%)$ had no symptoms. Preoperative urodynamic abnormalities were noted in 23 cases (74\%): abnormal urinary uroflow in 6 of 14 cases $(43 \%)$, residual urine of more than $30 \mathrm{ml}$ in 9 of 31 cases $(29 \%)$, abnormal cystometrogram and/or external sphincter EMG in 16 of 31 cases (52\%). These urodynamic abnormalities were closely correlated with perineal hyposensitivity.

Voiding function was re-examined in 22 patients after operation: improved in $14(64 \%)$, unchanged in $1(4 \%)$, worsoned in $2(9 \%)$ and normal in $5(23 \%)$ before and after operation. Therefore the above results could indicate that the presence of perineal hyposensitivity should be suspected to have voiding dysfunction in patients with IDP. Orthopedic surgery may improve voiding dysfunction in the majority of patients.

Key words: intervertebral disc prolapse, neurogenic bladder, urodynamic study

要旨：椎間板へルニアの手術目的に入院し，手術前に当科を受診した 31 例に問診による排尿異常と尿流 動態検査を施行した，椎間板ヘルニアの脊椎レベルは，頝胸椎 (C4-T10) 14例, 胸腰椎移行部 (T11-L2) 2 例, 腰椎（L2-S1）15例であった。術前排尿症状は，閉塞症状11例（36\%), 刺激症状 5 例（16\%）両 症状 5 例 (16\%)，無症状10例（32\%）であった。尿流動態検査では23例（74\%）に異常が認められた。 そのらち尿流率の低下は 14 例中 6 例 $(43 \%)$ に, $30 \mathrm{ml}$ 以上の残尿は 31 例中 9 例（29\%）に，膀胱内圧曲 線および外尿道括約筇筋電図異常が16例（52\%）にみられた。排尿機能異常は，肚門周囲知覚の低下と 相関した。手術後の排尿機能は, 22 例に評価可能で, 改善14例 (64\%), 不変 1 例 ( $4 \%$ ), 悪化 2 例 ( $9 \%$ ), 術前後とも異常なし 5 例（23\%）であった。従って，手術治療を必要とする春椎椎間板へルニアは神経 因性膀胱を高率に合併し，肛門周囲知覚検査は，排尿障害の存在を予測する上で簡単でしかも有用な検 查法であると考兄られた。また整形外科的手術による排尿障害の改善度は高く，悪化は少ないと考兄ら れた。

キーワード：椎間板ヘルニア，神経因性膀腃，尿流動態検査 


\section{緒 言}

脊椎椎間板へルニアにおける排尿障害については, Mixter and Barr (1934）ら"1の報告にはじまり，古く から多くの報告がある. 腰椎へルニアではかなり一致 した意見として，排尿障害を伴う事は稀であるが，中 心性の大きなへルニアに続発する事が多いとされてい た. O'Conell2), Robinson ら³はそれぞれ 2\%，5.4\% に排尿障害がみられたと報告した。しかしこれらは明 らかな尿閉あるいは尿失禁が見られた場合のみの頻度 である，手術前にさらに詳しい方法で排尿障害を検索

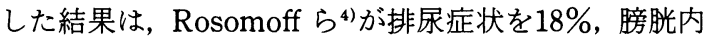
圧曲線異常を $83 \%$ に認めたと報告し，Mosdal ら5)は $55 \%$ に排尿症状を認め，47\%に膀胱内圧曲線異常を認 めたと報告した。 また頝椎椎間板へルニアの尿流動態 検査成績に関しては，Sandri $ら^{6}$ が手術後の結果を報 告したが，それ以外の尿流動態検査の報告は少なく， また整形外科的手術前後に於ける経過を詳細に観察し た報告も少ない，本報告の目的は，椎間板へルニアに 於ける尿流動態検査を手術前後に行い，術前の排尿障 害の有無および手術結果を検討することである。

\section{対象および方法}

対象は，椎間板へルニアにて手術前に当科を受診し た 31 例（男子 22 例，女子 9 例， $18 \sim 61$ 歳，平均 40 歳） である，椎間板へルニアの脊椎レベルは，頚胸椎 (C4T10）14例, 胸腰椎移行部（T11-L2）2 例, 腰椎（L2S1）15例であった，発生高位に関しては，頝胸椎では C5/6拈よびC6/7に次いで C4/5が多く, 腰椎では, L4/ 5が多く，次いでL5/S1の順であった（図 1 ）.

初診時の問診により，排尿症状の有無を，排尿困難， 尿閉等の閉塞症状と, 頻尿, 夜間頻尿, 尿意切迫, 尿 失禁等の刺激症状とに分け検討した。泌尿器科的検査 は，まず検尿，尿培養を行い，尿路感染の認められる ものは尿流動態検査前に抗菌剂投与により治療した。 必要により前立腺触診や尿道撮影, 排尿時膀胼尿道撮 影等により下部尿路を検索し，器質的下部尿路通過障 害（前立腺肥大症，尿道狭窄，膀胱䅡部硬化症）の明 らかなものは対象から除外した。

神経学的診察は，専門医により行われ，肛門周囲の 知覚, 膝蓋腱反射 (PTR), アキレス腱反射 (ATR), バビンスキー反射等の有無を調べた。また外尿道括約 筋筋電図検查施行時に肛門反射 (AR), 球海綿体筇反 射 (BCR) の有無についても検討した。

尿流動態検査は, Life-Tech 社製 Model 1154 Urorab または日本光電社製 Polygraph RM6000を用いて
国 1 Results of preoperative urodynamic study : : multiple protruded discs Overactive tonic: the gradual increase of detrusor pressure with filling charasteristic of reduced bladder compliance, Overactive phasic: typical phasic unstable detrusor contruction, High compliance: detrusor pressure shows little change without sensation when bladder is filled over $600 \mathrm{ml}$

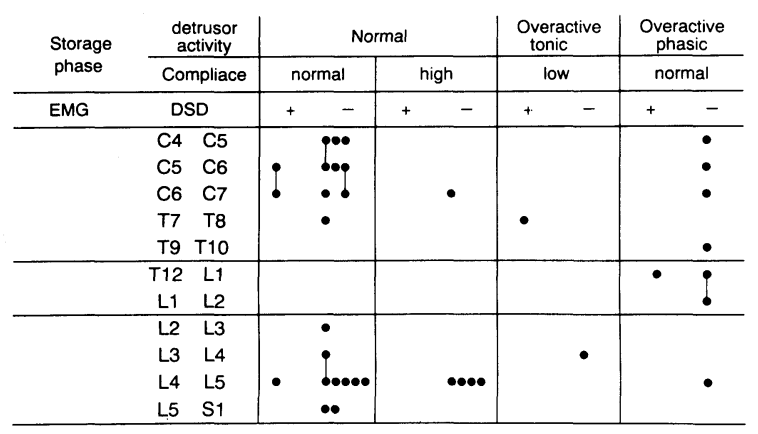

既報のごとく尿流測定, 残尿測定, 尿道内圧, 膀胼内 圧, 直腸内圧, 外尿道括約筋筋電図を測定し7)，その結 果は, ICS の基準に従い記録した ${ }^{8)}$ 。尿流測定は, 平均 尿流率, 最大尿流率を算出し, Siroky ら ${ }^{9}$ の判定基準に 従った。検査は, 手術前, および術後 1 力月〜 3 力月 の間に可及的に行い, その後は, 改善がみられなかっ た場合には，随時施行した。整形外科的手術における 結果は, 日本整形外科学会 (JOA) に打ける頝椎, 及 び腰椎疾患治療成績判定基準に基づき評価し，尿流動 態検査成績と比較検討した ${ }^{10)}$. 術後の経過は, 24 例に観 察可能で, その期間は，1 24力月, 平均 8 力月であっ た.

\section{結＼cjkstart果}

\section{1）排尿症状}

術前の排尿症状は，31例中閉塞症状が11例（36\%), 刺激症状が 5 例 (16\%), 両症状が 5 例 (16\%) に認め られ，全体として21例（68\%）に排尿症状が認められ た（表 1 ).

\section{2) 神経学的検查}

肛門反射, 球海綿体筋反射, 肛門周囲知覚の異常は, 頝胸椎部椎間板へルニア例ではそれぞれ $36 \% ， 36 \%$, $79 \%$ に, 胸腰椎移行部ではそれぞれ $50 \% ， 0 \% ， 100 \%$ に，腰椎ではそれぞれ $27 \% ， 13 \% ， 53 \%$ に認められた。 膝蓋腱反射やアキレス腱反射の異常, バビンスキー徵 候は頝胸椎ではそれぞれ $79 \% ， 71 \% ， 57 \%$ に, 胸腰椎 移行部ではそれぞれ $50 \% ， 50 \% ， 0 \%$ 腰椎ではそ 
表 1 Preoperative urinary symptoms and signs : case (\%)

\begin{tabular}{|c|c|c|c|c|c|c|c|c|c|c|c|}
\hline & \multirow{2}{*}{\multicolumn{4}{|c|}{ Urinary Symptoms }} & \multicolumn{7}{|c|}{ Neurological Signs } \\
\hline & & & & & AR & BCR & $\begin{array}{l}\text { penineal } \\
\text { sensory }\end{array}$ & PTR & ATR & \multirow{2}{*}{$\begin{array}{c}\text { Babinski } \\
\text { sign } \\
(+)\end{array}$} & \multirow[b]{2}{*}{ Total } \\
\hline & Obstructive & Irnitative & \begin{tabular}{|c|c} 
Obstructive \\
+ \\
Iritative \\
\end{tabular} & None & $\begin{array}{cc}\downarrow \\
\uparrow \\
\text { or } \\
(-)\end{array}$ & $\begin{array}{cc}\downarrow & \downarrow \\
\uparrow & \text { or } \\
& (-) \\
\end{array}$ & $\downarrow$ & $\begin{array}{c}\downarrow \\
\uparrow \\
\\
(-)\end{array}$ & $\begin{array}{c}\downarrow \\
\uparrow \\
\\
(-)\end{array}$ & & \\
\hline$C_{4}-T_{10}$ & $\begin{array}{c}5 \\
(36)\end{array}$ & $\begin{array}{c}3 \\
(21)\end{array}$ & $\begin{array}{c}2 \\
(14)\end{array}$ & $\begin{array}{c}4 \\
\text { (29) }\end{array}$ & $\begin{array}{cc}1 & 4 \\
(7) & (29)\end{array}$ & $\begin{array}{cc}4 & 1 \\
(29) & (7)\end{array}$ & $\begin{array}{c}11 \\
(79)\end{array}$ & $\begin{array}{c}11 \\
(79)\end{array}$ & $\begin{array}{cc}9 & 1 \\
(64) & (7)\end{array}$ & $\begin{array}{c}8 \\
(57)\end{array}$ & 14 \\
\hline$T_{11}-L_{2}$ & & $\begin{array}{c}1 \\
(50)\end{array}$ & $\begin{array}{c}1 \\
(50)\end{array}$ & & $\begin{array}{c}1 \\
(50)\end{array}$ & & $\begin{array}{c}2 \\
(100)\end{array}$ & $\begin{array}{c}1 \\
(50)\end{array}$ & $\begin{array}{c}1 \\
(50)\end{array}$ & & 2 \\
\hline $\mathrm{L}_{2}-\mathrm{S}_{1}$ & $\begin{array}{c}6 \\
(40)\end{array}$ & $\begin{array}{c}1 \\
\text { (7) }\end{array}$ & $\begin{array}{c}2 \\
(13)\end{array}$ & $\begin{array}{c}6 \\
(40)\end{array}$ & $\begin{array}{cc}1 & 3 \\
(7) & (20)\end{array}$ & $\begin{array}{c}2 \\
(13)\end{array}$ & $\begin{array}{c}8 \\
(53)\end{array}$ & $\begin{array}{cc}3 & 1 \\
(20) & (7)\end{array}$ & $\begin{array}{cc}1 & 4 \\
(7) & (26)\end{array}$ & $\begin{array}{c}1 \\
(7)\end{array}$ & 15 \\
\hline Total & $\begin{array}{c}11 \\
(36)\end{array}$ & $\begin{array}{c}5 \\
(16)\end{array}$ & $\begin{array}{c}5 \\
(16)\end{array}$ & $\begin{array}{c}10 \\
(32)\end{array}$ & $\begin{array}{cc}2 & 8 \\
(6) & (26)\end{array}$ & $\mid \begin{array}{cc}4 & 3 \\
(13) & (10)\end{array}$ & $\begin{array}{l}21 \\
(68)\end{array}$ & $\begin{array}{cc}15 & 1 \\
(48) & (3)\end{array}$ & $\begin{array}{cc}10 & 6 \\
(32) & (19)\end{array}$ & $\begin{array}{c}9 \\
(29)\end{array}$ & 31 \\
\hline & & & & & & $\begin{array}{l}R: \text { Anal } \\
C R \text { : Bulvo } \\
\text { TR : patell } \\
\text { TR : axillar }\end{array}$ & $\begin{array}{l}\text { Reflex } \\
\text { caverno } \\
\text { la tendo } \\
\text { i tendon }\end{array}$ & $\begin{array}{l}\text { sus reflex } \\
\text { reflex } \\
\text { reflex }\end{array}$ & & & \\
\hline
\end{tabular}

れぞれ $27 \% ， 33 \% ， 7 \%$ \%られた（表 1).

\section{3）尿流動態検查成績}

尿流測定は, 術前 14 例に施行し, 頚胸椎では 9 例中 4 例 (45\%), 腰椎では 5 例中 2 例 (40\%) に異常がみ られた。

残尿は 31 例全例に測定し, $30 \mathrm{ml}$ 末満を正常とした。 その結果は, 頝胸椎では $30 \mathrm{ml}$ 以上 4 例 $(29 \%), 100 \mathrm{ml}$ 以上 1 例 $(7 \%)$, 胸腰椎移行部では $30 \mathrm{ml}$ 以上 1 例 (50\%), 腰椎では $30 \mathrm{ml}$ 以上 1 例 $(7 \%), 100 \mathrm{ml}$ 以上 2 例 (13\%) であった。すなわち対象全体として正常22 例 $(71 \%), 30 \mathrm{ml}$ 以上が 6 例 (19\%), $100 \mathrm{ml}$ 以上が 3 例(10\%)であった. $100 \mathrm{ml}$ 以上のもの 3 例中 2 例は尿 閉状態であった。

膀脱内圧曲線, 直腸内圧および外尿道括約筋筋電図 同時測定は術前全例に施行した。膀腌内圧曲線に拈け る初発尿意量 (FDV) は, $100 \sim 300 \mathrm{ml}$ を正常, $100 \mathrm{ml}$ 以下を減少, $300 \mathrm{ml}$ 以上を増大とした。 その結果は, 正 常17例 (55\%), 减少 5 例 (16\%), 増大 9 例 (29\%) で，45\%に異常がみられた。最大尿意量（MDV）は, $300 \sim 600 \mathrm{ml}$ を正常とし, $300 \mathrm{ml}$ 以下を減少, $600 \mathrm{ml}$ 以 上を増大とした。その結果は, 正常21例(68\%), 減少 4 例（13\%)，増大 6 例（19\%）であった。全体として みると, 膀胼知覚の異常は, 14例 (45\%) にみられた。 膀胱内圧曲線は, 図 1 のごとくで, 頝胸椎では 6 例 (43\%), 胸腰移行部では 2 例(100\%)に異常がみられ, overactive (phasic) bladder がそれぞれ 4 例 (29\%), 2 例 (100\%) と多かった. 腰椎では 6 例 (40\%) に異 常が認められ, high compliance bladder が 4 例(27\%) と多かった。外尿道括約筋筋電図では, 術前排尿筋一外
尿道括約筋協調不全が頝胸椎の 2 例, 胸腰椎移行部の 1 例および腰椎の 1 例に認められた。従って膀胱内圧 曲線拉よび外尿道括約筇筇電図所見は，15例（48\%） が正常で，16例（52\%）が異常であった.

以上の, 尿流測定, 残尿測定, 膀胱内圧曲線, 外尿 道括約筋筇電図結果を総合して尿流動態検查成績をを とめると, 頚胸椎では 12 例 $(86 \%)$, 胸腰移行部では 2 例 $(100 \%)$, 腰椎では 9 例 $(60 \%)$, 全体として23例 （74\%）に異常が認められた。

\section{4）排尿症状と尿流動態検査成績}

排尿症状と膀胼内圧曲線との関係は図 2 の様にな $\eta$, high compliance および low compliance bladder は全例閉塞症状のみで, そのうち 2 例は尿閉状態で あった。 また, normal bladder と overactive(phasic) bladder はいずれの症状もみられたが，特に overactive (phasic) bladderのらちの50\%は無症状であっ

図 2 Relations between urinary symptoms and cystometric patterns

- : C4-T10, O : T11-L2, × : L2-S1

\begin{tabular}{|c|c|c|c|c|c|}
\hline \multirow{2}{*}{$\begin{array}{c}\text { Storage } \\
\text { phose }\end{array}$} & \multirow{2}{*}{$\begin{array}{l}\begin{array}{l}\text { detrusor } \\
\text { activity }\end{array} \\
\text { Compliace }\end{array}$} & \multicolumn{2}{|c|}{ Nomal } & \multirow{2}{*}{$\begin{array}{c}\begin{array}{c}\text { Overactive } \\
\text { tonic }\end{array} \\
\text { low } \\
\end{array}$} & \multirow{2}{*}{\begin{tabular}{|c|}
$\begin{array}{c}\text { Overactiue } \\
\text { phasic }\end{array}$ \\
Normal \\
\end{tabular}} \\
\hline & & Normal & high & & \\
\hline \multicolumn{2}{|c|}{ no symptom } & $x \times x \times$ & & & $\begin{array}{l}00 \\
0 \\
\times\end{array}$ \\
\hline \multicolumn{2}{|c|}{ obst ructive } & $\underset{x}{00}$ & $\underset{x \times x}{0}$ & $\stackrel{\bullet}{\times}$ & - \\
\hline \multicolumn{2}{|c|}{ irritative } & $\begin{array}{r}0 \\
\times\end{array}$ & & & ○ \\
\hline \multicolumn{2}{|c|}{$\begin{array}{l}\text { obstructive and } \\
\text { irritative }\end{array}$} & $\underset{x}{00}$ & & & 0 \\
\hline
\end{tabular}


表 2 Relationship between neurological signs and cystometric patterns: case (\%)

\begin{tabular}{|c|c|c|c|c|c|c|c|c|c|c|c|c|c|c|c|}
\hline & $\uparrow$ & $\begin{array}{c}\text { AR } \\
\vdots \\
\text { or } \\
(-)\end{array}$ & $\rightarrow$ & $\uparrow$ & $\begin{array}{c}\text { BCR } \\
\downarrow \\
\text { or } \\
(-)\end{array}$ & $\rightarrow$ & Anal S & ssory & $\uparrow$ & $\begin{array}{c}\text { PTR } \\
\downarrow \\
\text { or } \\
(-)\end{array}$ & $\rightarrow$ & & $\begin{array}{c}\text { ATR } \\
\downarrow \\
\text { or } \\
(-)\end{array}$ & $\rightarrow$ & Total \\
\hline normal & $\begin{array}{c}2 \\
(12)\end{array}$ & $\begin{array}{c}4 \\
(24)\end{array}$ & $\begin{array}{r}11 \\
(64)\end{array}$ & $\begin{array}{c}2 \\
(12)\end{array}$ & $\begin{array}{c}2 \\
(12)\end{array}$ & $\begin{array}{l}13 \\
(76)\end{array}$ & $\begin{array}{c}8 \\
(47)\end{array}$ & $\begin{array}{c}9 \\
(53)\end{array}$ & $\begin{array}{c}8 \\
(47)\end{array}$ & $\begin{array}{l}1 \\
(6)\end{array}$ & $\begin{array}{c}8 \\
(47)\end{array}$ & $\begin{array}{c}4 \\
(24)\end{array}$ & $\begin{array}{c}2 \\
(12)\end{array}$ & $\begin{array}{l}11 \\
(64)\end{array}$ & 17 \\
\hline $\begin{array}{l}\text { high } \\
\text { compliance }\end{array}$ & & $\begin{array}{c}1 \\
(20)\end{array}$ & $\begin{array}{c}4 \\
(80)\end{array}$ & $\begin{array}{c}1 \\
(20)\end{array}$ & $\begin{array}{c}1 \\
(20)\end{array}$ & $\begin{array}{c}3 \\
(60)\end{array}$ & $\begin{array}{c}4 \\
(80)\end{array}$ & $\begin{array}{c}1 \\
\text { (20) }\end{array}$ & $\begin{array}{c}1 \\
(20)\end{array}$ & & $\begin{array}{c}4 \\
(80)\end{array}$ & $\begin{array}{c}1 \\
(20)\end{array}$ & $\begin{array}{c}2 \\
(40)\end{array}$ & $\begin{array}{c}2 \\
(40)\end{array}$ & 5 \\
\hline $\begin{array}{l}\text { low } \\
\text { compliance }\end{array}$ & & $\begin{array}{c}1 \\
(50)\end{array}$ & $\begin{array}{c}1 \\
(50)\end{array}$ & $\begin{array}{c}1 \\
(50)\end{array}$ & & $\begin{array}{c}1 \\
(50)\end{array}$ & $\begin{array}{c}2 \\
(100)\end{array}$ & & $\begin{array}{c}1 \\
(50)\end{array}$ & & $\begin{array}{c}1 \\
(50)\end{array}$ & $\begin{array}{c}1 \\
(50)\end{array}$ & & $\begin{array}{c}1 \\
(50)\end{array}$ & 2 \\
\hline $\begin{array}{l}\text { overactive } \\
\text { (phasic) }\end{array}$ & & $\begin{array}{c}2 \\
(29)\end{array}$ & & & & $\begin{array}{c}7 \\
(100)\end{array}$ & $\begin{array}{c}7 \\
(100)\end{array}$ & & $\begin{array}{c}5 \\
(71)\end{array}$ & & $\begin{array}{c}2 \\
(29)\end{array}$ & $\begin{array}{c}4 \\
(57)\end{array}$ & $\begin{array}{c}2 \\
(29)\end{array}$ & $\begin{array}{c}1 \\
\text { (14) }\end{array}$ & 7 \\
\hline Total & 2 & 8 & 21 & 4 & 3 & 24 & 21 & 10 & 15 & 1 & 15 & 10 & 6 & 15 & 31 \\
\hline
\end{tabular}

た.

5）神経学的検査と尿流動態検査成績

神経学的検査と膀胖内圧曲線との関係は表 2 の様に なる. normal bladder では, AR, ATR 異常が約30\% に，また肚門周囲知覚低下が約半数にみられた。膀脂 内圧曲線異常例では, 肛門周囲知覚異常が 1 例を除き 全例にみとめられた。 また各反射と膀胱内圧曲線パ ターンとの関係では, high compliance bladder では AR, PTR は正常が $80 \%$ と多く, Overactive bladder ではATR, PTR え進例が多かった。

6）手術後の排尿機能

術後の排尿症状は24例に評価可能で, 閉塞症状 2 例 ( $8 \%$ ), 刺激症状 1 例 ( $4 \%$ ), 閉塞・刺激両症状 4 例 (16\%), 無症状17例（72\%）であった。従って術後の 排尿症状の改善度は, 術前後とも症状なし 9 例(38\%), 改善 9 例 $(38 \%)$, 不変 6 例 $(24 \%)$ で，悪化例は 1 例 もなかった。

尿流測定を手術前後で比較し得たのは 9 例で, 術後 正常化 2 例, 改善 3 例, 不変 1 例で, 術前後とも正常 3 例であった。残尿は, 術後14例に測定し, 正常化 4 例, 改善 2 例, 不変 1 例, 増大 2 例, 術前後之も正常 5 例であった。術後の膀脱内圧曲線, 外尿道括約筋筋 電図測定は13例に施行した. FDV は, 改善 5 例, 不変 2 例で, 術前後とも正常 6 例であった. MDVは, 改善 5 例, 不変 1 例, 術前後とも正常 7 例であった，従っ て膀胼知覚の改善度は, 改善 6 例, 不変 2 例, 術前後 とも正常 5 例であった. 術後の膀胼内圧曲線では, 4 例 $(31 \%)$ に異常がみられた。術前後を比較すると,
5 例は術前後とも正常で，4 例は術後正常化したが， 3 例は術前後とも異常で, 1 例は術後に異常が出現し た. 術後排尿笳一外尿道括約笳協調不全は 1 例消失し, 1 例は不変で， 1 例新たに出現した症例がみられた。 従って術前後の膀脱内王曲線および外尿道括約筋筋電 図の比較は，4 例 (31\%) 正常化し，3 例（23\%）不 変， 2 例 $(15 \%)$ 悪化で， 4 例 $(31 \%)$ は前後とも正 常であった。この結果と，尿流測定，残尿測定の結果 を合わせた，尿流動態検査成績の術前後における比較 を，14例について検討した結果，頝胸椎では正常化 2 例, 改善 2 例, 不変 1 例, 悪化 2 例, 胸腰椎移行部で は改善 1 例, 不変 1 例, 腰椎では正常化 2 例, 改善 3 例で, 全体として, 正常化 4 例 (29\%), 改善 6 例(43\%), 不変 2 例 $(14 \%)$, 悪化 2 例 $(14 \%)$ であった。

排尿症状及び尿流動態検査成績を総合した排尿障害 の改善度は22例に評価可能であった。その結果は，改 善14例 $(64 \%)$, 不変 1 例 $(4 \%)$, 悪化 2 例 ( $9 \%)$ で，手術前後とも排尿障害なし 5 例（23\%）であった。 覀化例は頝胸椎で, 不変例は頝椎および胸腰椎移行部 であった。この改善度と, JOAによる頝部, 及び腰椎 疾患治療成績判定基準にもとつく治療成績を比較する と ${ }^{10)}$, 図 3 の様になり，5例を除き両者は一致した。

\section{考察}

椎間板ヘルニアにおける排尿障害の頻度は, 以前は

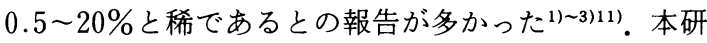
究の対象者は全例手術治療目的の患者であるが，排尿 症状が70\%に，尿流動態検査では $73 \%$ に高率に異常 が認められ，本症では神経因性膀胼は稀でないと考え 
目 3 Comparison of improvement of voiding dysfunction with orthopedic improvement determined by JOA criteria after orthopedic surgery

- : C4-T10, O : T11-L2, $\times$ : L2-S1

\begin{tabular}{|c|c|c|c|}
\hline voiding function & improved & unchanged & worsoned \\
\hline normal & $x \times \times \times x$ & & \\
\hline improved & $\underset{x \times x \times}{\bullet \bullet \bullet \bullet}$ & $\begin{array}{l}\dot{8} \\
\text { O } \\
\times\end{array}$ & \\
\hline unchanged & & 0 & \\
\hline worsoned & - & - & \\
\hline
\end{tabular}

られる。 また排尿障害は中心性のへルニアに発生する とされていたが(611) 13)，一般に多くみられる側方へル ニアでも神経因性膀胼は認められると考えられる. 我々の経験では明らかに中心性ヘルニアと記載されて いたものは(患者が拒否したために)手術を行わなかっ た頝椎ヘルニアの 1 例のみで, この例は, 今回の検討 から除外したが, high compliance bladderによる尿 閉と明らかな神経症状を伴っていた．本研究では整形 外科的手術前の患者を対象としたため, 保存的に治療 されている例を含めると排尿障害の頻度はさらに低い のであろら。しかし overactive bladder の約半数が無 症状であった事からも排尿症状が無いからといって必 ずしも排尿障害が無いとは言いきれず，手術適応を考 慮する場合は尿流動態検查等の泌尿器科的検査は必要 であろらと考える。

他の神経症状の特徵として, 尿流動態検査異常例に 肛門周囲の知覚異常が 1 例を除き全例にみられた。 ATR, PTR は, 特に尿流動態検査成績とに特徵的な関 係はなく, 肛門反射や球海綿体筋反射は正常例も多く, 特徵的な関係は無い様である。会陰部知覚の重要性は, O'Laoire ${ }^{14)}$, Gunaskera ${ }^{15)}$, Kostuik ら ${ }^{13)}$ 多報告してお り，我々の結果と一致すると考えられる.

整形外科的手術により排尿障害は $68 \%$ 改善し, 不変, 悪化がそれぞれ $4 \% ， 9 \%$ みであった事から，手術 効果は良好であると考兄られる。.Sandri'i ${ }^{6}$, Brooks $ら^{16)}$ は術後症例のみの検討で排尿機能の悪化例を報告 しているが，我々は全例術前に尿流動態検查を施行し ており, 術前正常な排尿機能の症例は手術による悪化 は認められず，悪化例はすべて術前異常例であった。 これらの悪化例は, 手術によるものか, 手術とは無関 係かは不明である。また JOA による治療成績判定基
準 ${ }^{10)}$ との比較では，排尿障害と他の症状の改善度はほ ぼ一致しているょらに思われる。しかし排尿症状や他 の神経症状が消失しているにもかかわらず尿流動態検 査を行うと, 䁤胼知覚が低下し, $90 \mathrm{ml}$ の残尿と overactive bladder が出現する様な例もあるので, 症状改 善の如何に関わらず尿流動態検査等により経過観察す る必要があると考えられる。

\section{結 語}

1）椎間板へルニア31例につき排尿障害の有無を整 形外科的手術前後で比較検討した.

2）術前の排尿症状は 21 例 (68\%) にみられ，その5 ち閉塞症状が11例 (36\%), 刺激症状が 5 例 (16\%), 閉塞・刺激両症状が 5 例（16\%）にみられた。

3）術前の尿流動態検查では，23例（74\%）に異常が みられた。

4）術後排尿障害改善度を22例につき検討した結果, 改善14例 $(64 \%)$, 不変 1 例 ( $4 \%$ ), 悪化 2 例 ( $9 \%)$ で，5例 (23\%) は術前後とも正常であった。

5）JOAによる治療成績判定基準と排尿障害改善度 を比較すると，ほぼ一致したが，そうでない例もみら れた。 また排尿症状と尿流動態検査の改善度が一致し ない例もみられたので, 症状の改善如何に関わらず経 過観察が必要であると考えられる。

\section{文献}

1) Mixter, W.J. and Barr, J.S.: Rupture of the intervertebral disc with involvement of the spinal canal. N. Engl. J. Med, 211, 210-215, 1934.

2) O'Connell, J.E.: Protrusions of the lumbar intervertebral discs. E. Bone Joint Surg, 33B, 8 $-30,1951$.

3) Rebinson, R.G.: Massive protrusions of lumbar discs. Brit. J. Surg, 52, 858-865, 1965

4) Rosomoff. H.L., Johnston, J.D.H., Gallo. A.E., Ludmer, M., Givens, F.T., Carney, F.T. and Kuehn, C.A.: Cystometry as an adjunct in the evalation of lumbar disc syndromes. J. Neurosurg, 33, 67-74, 1970.

5) Mosdal, C., Iversen, P. and Iversen-Hansen, R. : Bladder neuropathy in lumbar disc disease. Acta. Neurochirurgica, 46, 281-286, 1979.

6) Sandri, S.D., Fanciullacci, F. and Zanollo, A.: Urinary disorders in intervertebral disc prolapse. Neurouro. Urodyn, 6, 11-19, 1987.

7) 安田耕作, 浜 年樹, 中山朝行, 香村衡一, 山城 豊, 島崎 淳, 服部孝道, 平山恵造：Detrusor sphincter dyssynergia. 日泌尿会誌, 73, 988-995, 
1982.

8) Internal continence society committee on standardization of terminology: The standardization of terminology of lower urinary tract func. tion. Scan. J. Urol. Nephrol, 114, 5-19, 1988.

9) Siroky, M.B. and Osloon, C.A. The flow rate nomogram: II Clinical correlation. J. Urol, 123, 208-210, 1980.

10）泉田重雄, 井上駿一：会告, 腰痛治療成績績判定基 準. 日整会誌，60，391-394，1986.

11）島屋雅光, 林 輝明, 島潟泰仁: 馬尾圧迫型椎間板 ヘルニアについて. 整形外科, 25.769-776, 1974.

12) Ross, J.C. and Jameson, R.M : Vesical dysfunction due to prolapsed disc. Brit. Med. J, 25, 752 $-754,1971$,

13) Kostuik, J.P, Harrington I, Alexander D, Ránd, W. and Evans, D.: Cauda equina syndrome and lumbar disc herniation. J. Bone Joint Suqg, 68A, 386-391, 1986.

14) O' Raoire, S.A., Crockard, H.A. and Thomas, D. G. : Prognosis for sphincter recovery after operation for cauda equina compression owing to lumbar disc prolapse. Brit. Med. J, 282, 1852 $-1854,1981$.

15) Gunasekera, W.S.L., Richardson, A.E., Seneviratne, K.N. and Eversden, I.D.: Clinical correlation of urodynamic findings in patients with localized partial lesions of the spinal cord and cauda equina. Surg. Neurol, 21, 148-154, 1984.

16) Brooks, M.E., Moreno, M., Sidi, A. and Braf, Z. : Urologic complications after surgery on lumbosacral spine. Urology, 116, 202-204, 1985.

(1991年 1 月16日受理) 